\title{
A fuzzy DEMATEL based sustainable development index (FDSDI) in open pit mining - a case study
}

The Mining-Geology-Petroleum Engineering Bulletin UDC: 622.2

DOI: 10.17794/rgn.2020.1.1

Professional paper

\author{
Mohammad Ataei ${ }^{1}$, Raziye Norouzi Masir ${ }^{1}$ \\ ${ }^{1}$ Faculty of Mining, Petroleum and Geophysics Engineering, Shahrood University of Technology, Shahrood, Iran.
}

\begin{abstract}
As an economic activity, mining can have positive and negative effects for the community. These negative impacts along with some of the social, economic, and environmental impacts of mining actions threaten the achievement of sustainable development (SD) goals. Therefore, an impact evaluation of SD indexes is significant for protecting mining actions in line with the objectives of SD. For that reason, a system classification was proposed with the use of the fuzzy decisionmaking trial and evaluation laboratory (fuzzy DEMATEL) technique to study and analyse eleven impacting factor interrelationships in open pit mines. Since this technique is based upon the opinion of experts, the fuzzy coding technique was used. In this manner, the weight of the impacting factors and their related ratings were chosen to develop a new classification system. Based on the proposed rating system, FDSDI was introduced to describe system-levels qualitatively and quantitatively. The application of FDSDI was investigated in a bauxite mine as a case study. The results show that FDSDI is an easy and effective tool to evaluate sustainability in bauxite mining. Generally, the conducted technique presents a systematic approach for holistic analysis of the impacting factors of SD in open pit mines.
\end{abstract}

Keywords:

Fuzzy decision-making trial and evaluation laboratory, classification system, zone, Jahjarm bauxite mine

\section{Introduction}

Nowadays, due to increases in the world population and the growing demand for an increase in the production rate of minerals, industries are necessary. In the world, production is important in open-pit mines. More than 90 percent of Iran's mines have been mined by using open pit mining techniques, which have a considerable share in creating jobs, supplying essential raw materials, income distribution, expanding social infrastructures and the economics of the country (Moradi, and Osanloo, 2015; Norouzi Masir et al., 2018). Regardless of all these benefits, mining activities lead to the production of many hazards for the health and safety of mineworkers, damage to the natural environment (e.g. water, air, and soil pollution, land disruption, subsidence), and various social problems (Marker et al., 2005; Owen and Kemp, 2017). In this regard, if the increase in the production rate is not monitored, future generations will have problems. In this regard, sustainable development (SD) has been widely used to deal with these issues and challenges. Understanding sustainable development practices can be a useful tool to help solve these issues, and thus, using SD has become an important topic in international business studies (Campbell et al.,

Corresponding author: Mohammad Ataei

ataei@shahroodut.ac.ir
2012; Egri and Ralston, 2008; Vivoda and Kemp, 2019). Hence, in this paper, SD assessment has been used, because it pays attention to SD in mining activities, reduces environmental problems, and has positive social and economic effects (Norouzi Masir et al., 2018; Buchanan and Marques, 2018; Dashwood, 2012).

The concept of SD is now widely spread. There are several definitions and schools of thought of SD available in literature. One such publication on SD was released by the World Commission on Environment and Development at the United Nations in 1987 in a report entitled "Our Common Future" as it "meets the needs of the present without compromising the ability of the future generations to meet their own needs" (Brundtland Report, 1987). This issue was discussed in the United Nations Conference on development and the environment in Rio de Janeiro in 1992, causing business organizations universally to begin to adopt SD policies (Gladwin et al., 1995; Stoughton and Ludema, 2012). Generally, this report shows that developing countries have presented models, taken innovations and are more committed to achieving the goals of SD than their counterparts in the developed world. Basically, SD is a practical requirement and needs universal support to ensure that economic actions are realized in an advanced society, and yet still leave a well-preserved environment (Sachs and Reid, 2006; DES, 2013). The implementa- 


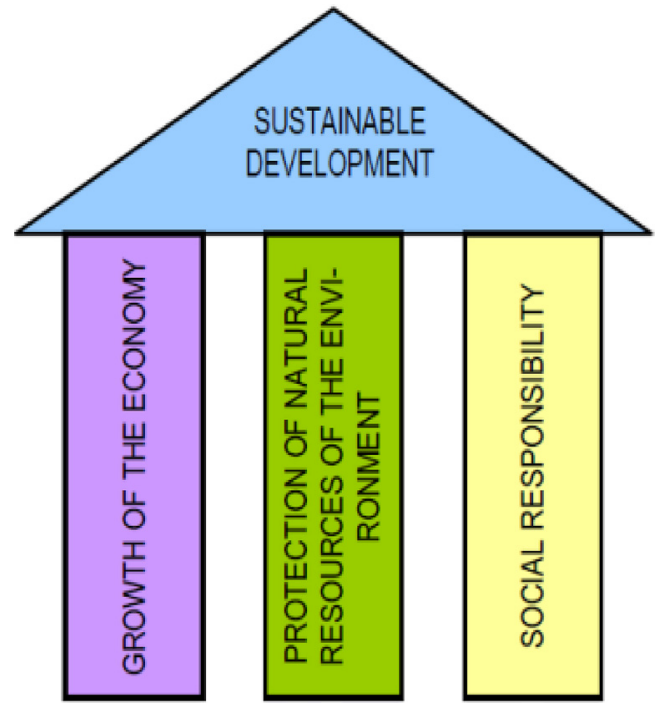

Figure 1: Key aspects of SD (Dubinsky, 2013) tion of SD means a combination of activities in the following three key parts (see Figure 1) (Dubinsky, 2013):

Technical and economic, ensuring economic growth,

Environmental, guaranteeing the protection of natural resources and the natural environment,

Social, paying attention to employment and community development.

Since the early 1990 s, SD studies in the mining industry have been presented and in 1992, the concept of SD gained interest among miners from the United Nation's Earth Summit Conference in Rio de Janeiro, Brazil (Osanloo and Rahmanpour, 2017). Since then, different studies of SD in the mining industry have been presented (Allen, 1991; Auty and Warhust, 1993; VonBelow, 1993; Mikesell, 1994; Allan 1995; Tilton, 1996; Learmont, 1997; Carbon, 1997; James, 1999; Hilson and Murck 2000; Hilson and Basu, 2003; Rajaram et al.,

Table 1: Summary aspects of SD research in open pit mining

\begin{tabular}{|c|c|c|c|c|}
\hline Reference & Study type & Study origin & Case & Major objective/outcome \\
\hline $\begin{array}{l}\text { Gardner and Bell, } \\
(2007)\end{array}$ & $\begin{array}{l}\text { Survey and case } \\
\text { study }\end{array}$ & Australia & Alcoa mine & $\begin{array}{l}\text { Discussed Bauxite mining restoration social, } \\
\text { political, historical, and environmental } \\
\text { contexts. }\end{array}$ \\
\hline $\begin{array}{l}\text { Rashidinejad et al. } \\
\text { (2008) }\end{array}$ & Survey & General & & $\begin{array}{l}\text { offered an environmental oriented model } \\
\text { for optimum cut-off grades }\end{array}$ \\
\hline $\begin{array}{l}\text { Monjezi et al. } \\
(2009)\end{array}$ & $\begin{array}{l}\text { Survey and case } \\
\text { study }\end{array}$ & Iran & $\begin{array}{l}\text { Mouteh gold mine, } \\
\text { Gol-eGohar mine, } \\
\text { Chogart iron mine, and } \\
\text { Sarcheshmeh copper } \\
\text { mine }\end{array}$ & $\begin{array}{l}\text { Reviewed Folchi method for the EIA of } \\
\text { open-pit mining in Iran. }\end{array}$ \\
\hline $\begin{array}{l}\text { Pavloudakis et al. } \\
(2009)\end{array}$ & $\begin{array}{l}\text { Survey and case } \\
\text { study }\end{array}$ & $\begin{array}{l}\text { Northern } \\
\text { Greece }\end{array}$ & $\begin{array}{l}\text { Amynteon lignite } \\
\text { surface mine }\end{array}$ & $\begin{array}{l}\text { Developed a spatial decision support system } \\
\text { for the optimal environmental reclamation } \\
\text { of open-pit coal mines. }\end{array}$ \\
\hline Philips, (2012) & $\begin{array}{l}\text { Survey and case } \\
\text { study }\end{array}$ & India & Andhra Pradesh mine & $\begin{array}{l}\text { Applied a mathematical model of } \\
\text { sustainability to the environmental impact } \\
\text { assessment (EIA) of a proposed bauxite } \\
\text { mining project. }\end{array}$ \\
\hline $\begin{array}{l}\text { Temper and } \\
\text { Martinez-Alier, } \\
(2013)\end{array}$ & $\begin{array}{l}\text { Survey and case } \\
\text { study }\end{array}$ & India & $\begin{array}{l}\text { Odisha and the } \\
\text { Lanjigarh refinery }\end{array}$ & $\begin{array}{l}\text { Described an environmental and } \\
\text { institutional history for determining Net } \\
\text { Present Value (NPV). }\end{array}$ \\
\hline $\begin{array}{l}\text { Badiozamani and } \\
\text { Askari-Nasab, } \\
(2014)\end{array}$ & $\begin{array}{l}\text { Survey and case } \\
\text { study }\end{array}$ & - & $\begin{array}{l}\text { Real dataset of oil } \\
\text { sands mine }\end{array}$ & $\begin{array}{l}\text { Assessed a new mixed integer linear } \\
\text { programming model (MILP) model to } \\
\text { maximize the NPV by considering the } \\
\text { reclamation costs in its aims function. }\end{array}$ \\
\hline $\begin{array}{l}\text { Lad and Samant, } \\
(2015)\end{array}$ & $\begin{array}{l}\text { Survey and case } \\
\text { study }\end{array}$ & India & $\begin{array}{l}\text { Udgiri, Dist-Kolhapur, } \\
\text { Maharashtra State }\end{array}$ & $\begin{array}{l}\text { Described the impact of bauxite mining } \\
\text { on soil pollution. }\end{array}$ \\
\hline $\begin{array}{l}\text { Narrei and Osanloo. } \\
(2015)\end{array}$ & $\begin{array}{l}\text { Survey and case } \\
\text { study }\end{array}$ & Iran & Gol-Gohar iron mine & $\begin{array}{l}\text { Provided a model for determining cut off } \\
\text { grades by considering possible incomes } \\
\text { from reclamation }\end{array}$ \\
\hline Leblanc et al. (2015) & $\begin{array}{l}\text { Survey and case } \\
\text { study }\end{array}$ & Australia & Cape York Peninsula & $\begin{array}{l}\text { Proposed a study on the hydrology of the } \\
\text { bauxite oases. }\end{array}$ \\
\hline $\begin{array}{l}\text { Amirshenava and } \\
\text { Osanloo (2018) }\end{array}$ & $\begin{array}{l}\text { Survey and case } \\
\text { study }\end{array}$ & Iran & Choghart iron ore mine & $\begin{array}{l}\text { Presented a general procedure for mine } \\
\text { closure risk management. }\end{array}$ \\
\hline $\begin{array}{l}\text { Srikanth and Nathan } \\
\text { (2018) }\end{array}$ & $\begin{array}{l}\text { Review and case } \\
\text { study }\end{array}$ & India & Surface coal mines & $\begin{array}{l}\text { Studied the surface coal mine closure } \\
\text { policies }\end{array}$ \\
\hline
\end{tabular}


2005; Eggert, 2006; Horowitz, 2006). This research shows how mining and minerals can contribute to SD.

As mentioned before, nowadays, most of the minerals are produced by open pit mining methods and these operations affect the aspects of SD (environmental, social and economic). A summary of environmental, environmental-economic and environmental-social studies aspects of SD research in open pit mining is presented in Table 1.

As can be seen in Table 1, a number of studies didn't consider all aspects of SD in open pit mines (environmental, economic and social) together while these aspects are related to each other. In the following segment, recent research in this context is reviewed.

In 2004, Ramirez-Rodriguezm and Rozgonyi, estimated the cut-off grade using Lane's algorithm, one of the most popular algorithms for determination of the optimum cut-off grade, by applying the cost of reconstruction in the design and planning of open pit mines. The results indicated that the integration of the SD requirements in mining profitability and optimum cut-off grades is very necessary. Rahimi and Ghasemzadeh in $\mathbf{2 0 1 5}$ offered a new algorithm for the determination of the optimum cut-off grades by considering SD aspects. This research showed that applying hydrometallurgical techniques for low grade copper ores instead of pyrometallurgical ones not only improves the NPV of copper mines but also reduces the adverse environmental effects and creates sustainable results from mining operations. Moradi and Osanloo, in 2015, studied prioritizing SD aspects affecting open pit mine design using the Preference Voting System (PVS) based on a model of DEA. The results showed that this research can be offered unique standards in the SD impacting factors ultimate pit limit (UPL) design in different metal mines, and the shares of the environmental, economic and social aspects are 26, 38 and $36 \%$, respectively. Adibi and Ataee-pour, in 2015, developed a model based upon SD aspects to consider the economic and social benefits and decrease the negative environmental impacts of an open pit mine during UPL design and before exploitation. The presented model was explained with a simple 2D example and used in the Jalalabad iron mine as a case study. The results indicated that when the mining investor ignores a little of the mining profit, improvement in all aspects of SD in mining is possible. In the same study, Adibi et al. in 2015, reused the mentioned model in a copper mine for solving the "UPL selection based upon SD aspects" problem utilizing the TOPSIS technique. The paper analysis indicated that the UPL selected by the proposed technique had higher social and economic ratings compared to the traditional UPL. It also contained greater ore and lower profit than the traditional UPL. Rahmanpour and Osanloo in 2017, in a study project offered two mining plans in the Sungun copper mine with the title "mine design selection considering SD", one based upon maximizing the maximum net pre- sent value of the mine and the other for maximizing the lifetime of the mine, utilizing the Folchi technique to determine which plan had more validity based on the aspects of SD.

Although this research has provided a significant role in the assessment of SD in open pit mining, the greatest shortcoming of these studies is developing a comprehensive evaluation related to a classification system of SD issues in open pit mining. In addition, no scientific or systematic approach by using fuzzy DEMATEL was applied to quantitatively evaluate the weighting of impacting parameters in open pit mining. Accordingly, this paper presents a generic procedure for qualitatively and quantitatively evaluating impacting factors in open pit mining operations in a SD index. Finally, this index was assessed in a real case.

\section{Method}

\subsection{Fuzzy DEMATEL method}

Fuzzy DEMATEL is a common and efficient method for decision making. The fuzzy DEMATEL technique is a strategy for constructing an efficient group communication method. It provides feedback on contributions of knowledge and evaluation of group experts to enable individuals to assess their viewpoints. Actually, an individual's opinion with preferences in decision-making, generally, is often uncertain and difficult to calculate by accurate numerical values, thus the use of fuzzy logic is a necessity. That's why, to deal with the uncertainty of individual evaluations, the preferences of experts are increased to fuzzy numbers by accepting the fuzzy linguistic scale. (Fontela and Gabus 1972, 1974, 1976).

In this article, by using triangular fuzzy numbers (TFN) in the fuzzy DEMATEL method, the relative fuzzy weights of the decision factors are estimated utilizing the five stages mentioned below and the relative fuzzy weights are accumulated to obtain scores for the impacting factors (Mohammadi et al., 2018):

Stage 1: Obtaining the initial and average direct relation matrix. For this aim, judgments show the direct influence that factors $i$ judgments on the criterion $j$ utilizing a TFN. The TFN corresponding to every one of the linguistic scales is shown in Table 2.

If there are $h$ experts and $n$ factors, so each expert makes the $n \times n$ non- negative matrix $\tilde{Z}^{k}$, with $1 \leq k \leq h$.

Table 2: Fuzzy linguistic comparison chart

\begin{tabular}{|l|l|}
\hline Linguistic terms & Linguistic value \\
\hline Very High Influence $(\mathrm{VH})$ & $(0.75,1.0,1.0)$ \\
\hline High Influence $(\mathrm{H})$ & $(0.5,0.75,1.0)$ \\
\hline Low Influence $(\mathrm{L})$ & $(0.25,0.5,0.75)$ \\
\hline Very Low Influence (VL) & $(0,0.25,0.5)$ \\
\hline No Influence (NO) & $(0,0,0.25)$ \\
\hline
\end{tabular}


Hence, $\tilde{Z}^{1}, \tilde{Z}^{2}, \ldots, \tilde{Z}^{h}$ are the resulting matrices for each of the $h$ experts. The elements of $\tilde{Z}^{k}$ are $\tilde{z}_{i j}=\left(1_{i j}, m_{i j}, u_{i j}\right)$ which in the first, second, and third terms represent the lower, middle, and upper bounds of TFN that shows the direct influence of factor $i$ on factor $j$ based on the opinion of $k^{\text {th }}$ expert. $\tilde{A}$ is illustrated as Equation 1:

$$
\tilde{A}=\frac{\left(\tilde{Z}^{1} \oplus \tilde{Z}^{2} \oplus \ldots \oplus \tilde{Z}^{h}\right)}{h}
$$

Where:

$\tilde{Z}^{k}$ - Direct relation fuzzy matrix,

$\tilde{A}$ - Average direct relation matrix,

$\mathrm{h}$ - Expert's value.

Stage 2: Establishing the normalized direct relation matrix. The normalized direct relation matrix $\tilde{X}$ is achieved via normalizing the matrix $\tilde{A}$ presented as Equation 2 and 3:

$$
\begin{gathered}
\tilde{X}=\frac{\tilde{A}}{r} \\
r=\max \left[\max _{1 \leq i \leq n} \sum_{j=1}^{n} u_{i j}, \max _{1 \leq j \leq n} \sum_{i=1}^{n} u_{i j}\right], \\
i, j=1,2, \ldots, n .
\end{gathered}
$$

Let $\tilde{x}_{i j}=\left(1_{i j}^{\prime}, m_{i j}^{\prime}, u_{i j}^{\prime}\right)$ be the factors of $\tilde{X}$ and describes three crisp matrices, whose factors are extracted from $\tilde{X}$ as follows:

$$
\begin{gathered}
X_{l}=\left[\begin{array}{cccc}
0 & l_{12}^{\prime} & \cdots & l_{1 n}^{\prime} \\
l_{21}^{\prime} & 0 & \cdots & l_{2 n}^{\prime} \\
\vdots & \vdots & \ddots & \vdots \\
l_{n 1}^{\prime} & l_{n 2}^{\prime} & \cdots & 0
\end{array}\right] \quad X_{m}=\left[\begin{array}{cccc}
0 & m_{12}^{\prime} & \cdots & m_{1 n}^{\prime} \\
m_{21}^{\prime} & 0 & \cdots & m_{2 n}^{\prime} \\
\vdots & \vdots & \ddots & \vdots \\
m_{n 1}^{\prime} & m_{n 2}^{\prime} & \cdots & 0
\end{array}\right] \\
X_{u}=\left[\begin{array}{cccc}
0 & u_{12}^{\prime} & \cdots & u_{1 n}^{\prime} \\
u_{21}^{\prime} & 0 & \cdots & u_{2 n}^{\prime} \\
\vdots & \vdots & \ddots & \vdots \\
u_{n 1}^{\prime} & u_{n 2}^{\prime} & \cdots & 0
\end{array}\right]
\end{gathered}
$$

Where:

$l_{\mathrm{ij}}$ - lower bounds of TFN value,

$\mathrm{m}^{\mathrm{ij}}$ - middle bounds of TFN value,

$\mathrm{u}_{\mathrm{ij}}$ - upper bounds of TFN value.

Stage 3: Estimating the total relation matrix. The total relation matrix $\tilde{T}$ is estimated utilizing following formulas (see Equation 4 and 5):

$$
\tilde{T}=\tilde{X}(\mathrm{I}-\tilde{X})^{-1}
$$

Where:

I - the unit matrix.

Let

$$
\tilde{T}=\left[\begin{array}{cccc}
\tilde{t}_{11} & \tilde{t}_{12} & \cdots & \tilde{t}_{1 n} \\
\tilde{t}_{21} & \tilde{t}_{22} & \cdots & \tilde{t}_{2 n} \\
\vdots & \vdots & \ddots & \vdots \\
\tilde{t}_{n 1} & \tilde{t}_{n 2} & \cdots & \tilde{t}_{n n}
\end{array}\right]
$$

Where its elements are $\tilde{t}_{i j}=\left(l_{i j}^{\prime \prime}, m_{i j}^{\prime \prime}, u_{i j}^{\prime \prime}\right)$. With regards to the crisp case, the crisp factors of total relation matrices estimated as:

$$
\begin{gathered}
\mathrm{T}_{l}=\left[l_{i j}^{\prime \prime}\right]=X_{l}\left(\mathrm{I}-X_{l}\right)^{-1} ; \mathrm{T}_{m}=\left[\mathrm{m}_{i j}^{\prime \prime}\right]=X_{m}\left(\mathrm{I}-X_{m}\right)^{-1} ; \\
\mathrm{T}_{u}=\left[u_{i j}^{\prime \prime}\right]=X_{u}\left(\mathrm{I}-X_{u}\right)^{-1}
\end{gathered}
$$

Where:

$1{ }^{\prime i j}$ - lower bounds of TFN value,

$\mathrm{m}^{\prime \prime}$ ij - middle bounds of TFN value,

u" ${ }_{\mathrm{ij}}$ - upper bounds of TFN value.

Stage 4: Set up the causal diagram. After obtaining matrix $\tilde{T}$, sum of rows (r) and sum of columns (c) of the total relation matrix based on the formula are estimated in Equations 6 and 7:

$$
\begin{aligned}
& {\left[r_{i j}\right]_{n \times 1}=\left(\sum_{j=1}^{n} l_{i j}, \sum_{j=1}^{n} m_{i j}, \sum_{j=1}^{n} u_{i j}\right), \quad i, j=1,2, \ldots, \mathrm{n}} \\
& {\left[c_{i j}\right]_{1 \times n}=\left(\sum_{i=1}^{n} l_{i j}, \sum_{i=1}^{n} m_{i j}, \sum_{i=1}^{n} u_{i j}\right), \quad i, j=1,2, \ldots, \mathrm{n}}
\end{aligned}
$$

Where:

$\mathrm{r}$ - the total exert influence on the others,

$\mathrm{c}$ - the total influence received from the others,

$1_{\mathrm{ij}}$ - lower bounds of TFN value,

$\mathrm{m}_{\mathrm{ij}}$ - middle bounds of TFN value,

$\mathrm{u}_{\mathrm{ij}}$ - upper bounds of TFN value.

Stage 5: Computing the weight of criterion. At this stage, the weight of every factor $(\tilde{W} i)$ is specified as Equation 8:

$$
\tilde{w}_{i}=\left(\frac{l_{r_{i}}+l_{c_{i}}}{\sum_{i=1}^{n} l_{r_{i}}+\sum_{i=1}^{n} l_{c_{i}}}, \frac{m_{r_{i}}+m_{c_{i}}}{\sum_{i=1}^{n} m_{r_{i}}+\sum_{i=1}^{n} m_{c_{i}}}, \frac{u_{r_{i}}+u_{c_{i}}}{\sum_{i=1}^{n} u_{r_{i}}+\sum_{i=1}^{n} u_{c_{i}}}\right) \text { (8) }
$$

At this stage, the results of fuzzy DEMATEL is a fuzzy number. Thus, the defuzzification of fuzzy numbers is a compulsory issue. For this aim, the Best Nonfuzzy Performance (BNP) technique was applied to defuzzification the values of $\mathrm{r}, \mathrm{c}$, and $\tilde{W} i$ which is described based on Equation 9:

Where:

$$
B N P=l+\frac{(\mathrm{u}-1)+(\mathrm{m}-1)}{3}
$$

1 - lower bounds of TFN value, $\mathrm{m}$ - middle bounds of TFN value, $\mathrm{u}$ - upper bounds of TFN value.

\subsection{Development of a new classification system}

In order to present a classification system for evaluating $\mathrm{SD}$, it is necessary to identify the most significant parameters that govern SD performance. For this purpose, the following rules were taken into account: 


$\begin{array}{cccc}\text { Environmental }\left(c_{1}\right) & \text { Economic }\left(c_{2}\right) & \text { Social }\left(c_{3}\right) \\ \square \quad & \text { Air pollution }\left(c_{11}\right) & \text { Fixed price }\left(c_{21}\right) & \begin{array}{c}\text { Employment of local work } \\ \text { force }\left(c_{31}\right)\end{array} \\ \square \quad \text { Water pollution }\left(c_{12}\right) & \begin{array}{c}\text { Early closure of the mine } \\ \left(c_{32}\right)\end{array} \\ \square \quad \text { Soil pollution }\left(c_{13}\right) & \square \quad \begin{array}{c}\text { Skills and knowledge }\left(c_{33}\right) \\ \square \quad \text { Noise }\left(c_{14}\right)\end{array} & \begin{array}{l}\text { Health and safety }\left(c_{34}\right) \\ \square \quad \text { Land disturbance }\left(c_{15}\right)\end{array} & \\ \square \quad \text { Energy and fuel }\left(c_{16}\right) & & \end{array}$

Figure 2: Impacting factors involved for a SD

- Utilizing the minimum number of parameters,

- The non-parallel and non-overlapping parameters,

- The ease of measurement of parameters, and

- The definition of ability in a wide range of bauxite measure environs (parameters generality).

Based on the above rules, for presenting a classification system of SD, 11 impacting factors were selected by considering the literature review, experts' opinions, and our own analysis as illustrated in Figure 2.

By analysing the impacting factors on the $\mathrm{SD}$, the direct relation matrix was established as displayed in Figure 3.

$$
X=\left[\begin{array}{cccc}
0 & x_{12} & \ldots & x_{1 n} \\
x_{21} & 0 & \ldots & x_{2 n} \\
\vdots & \vdots & \ddots & \vdots \\
x_{n 1} & x_{n 2} & \cdots & 0
\end{array}\right]
$$

Figure 3: Direct relation matrix

In the direct relation, the matrix was evaluated using the fuzzy DEMATEL method. To establish the direct relation matrix, questionnaires were distributed among 20 academics and industrial experts and their opinions and judgments were collected, where 15 questionnaires were

Table 3: The crisp matrix of the fuzzy total relation matrix

\begin{tabular}{|c|c|c|c|c|c|c|c|c|c|c|c|c|c|c|c|c|c|c|c|c|c|c|c|c|c|c|c|c|c|c|c|c|}
\hline & & & & & & & & & & & & & & & & & & & & & & & & & & & & & & & & \\
\hline & & & & & & & & \begin{tabular}{l|} 
\\
$\dot{\AA}$ \\
$\dot{1}$
\end{tabular} & & & & & & & & & & & & & & & & & & \begin{tabular}{l|l} 
\\
$\dot{2}$
\end{tabular} & & & & $\begin{array}{lll}\mathscr{B} \\
0\end{array}$ & 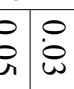 & \\
\hline & & $=$ & & & & & & & & & & & & & & & & & & & & & & & & & & & & & & \\
\hline & & & & & & & & & & & & & & & & & & & & & & & & & $\begin{array}{l}\text { lo } \\
\text { in }\end{array}$ & & & & & & $\Phi$ & \\
\hline & & & & & & & & & & & 0 & & & & & & 0 & & & 0 & & $\mathrm{~N}$ & & & $N$ & $\stackrel{\circ}{\circ}$ & 0 & & & & & \\
\hline & & & & & & & & & & & 0 & & & 0 & & & & & & & & & & & & & & & & & & \\
\hline & & & & & & & & & & & & & & & & & & & & & & & & & & & & & & & & \\
\hline & & $\omega$ & & & $\stackrel{\circ}{\dot{9}}$ & & & $\begin{array}{l}\stackrel{0}{0} \\
\dot{\omega}\end{array}$ & & & 0 & & & $\dot{0}$ & & & & & & & & & & & & & & & & & & \\
\hline & & 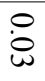 & & & $\begin{array}{l}\text { Po } \\
\dot{0}\end{array}$ & & & $\stackrel{\circ}{\circ}$ & & & & & & $\begin{array}{l}\dot{0} \\
\dot{0} \\
\dot{u}\end{array}$ & & & $\begin{array}{l}8 \\
\dot{2} \\
ن \\
4\end{array}$ & & & $\begin{array}{l}0 \\
\dot{0} \\
\dot{0}\end{array}$ & & & $\stackrel{8}{\circ}$ & & & $\begin{array}{l}0 \\
\dot{2}\end{array}$ & & 09 & & & & \\
\hline & & $\dot{0}$ & & & $\begin{array}{l}\dot{P} \\
\dot{0}\end{array}$ & & & $\begin{array}{l}\dot{0} \\
\dot{\sim}\end{array}$ & & & & & & $\begin{array}{l}\circ \\
\dot{0} \\
\dot{0}\end{array}$ & & & $\begin{array}{l}8 \\
\dot{8} \\
\dot{8}\end{array}$ & & & $\begin{array}{l}0 \\
\dot{0} \\
ن\end{array}$ & & & 0 & & & $\dot{\sim}$ & & 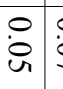 & & & & \\
\hline & & 0 & & & $\stackrel{\circ}{\circ}$ & & & $\stackrel{0}{0}$ & & & & & & $\begin{array}{l}\dot{1} \\
\dot{1}\end{array}$ & & & $\begin{array}{l}\dot{0} \\
\dot{\omega}\end{array}$ & & & $\begin{array}{l}8 \\
\dot{8}\end{array}$ & & & & & & $\stackrel{\circ}{\circ}$ & & & & & $\begin{array}{ll}8 & \stackrel{8}{8} \\
8 & \dot{8}\end{array}$ & 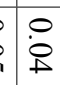 \\
\hline & & & & & & & & 0 & & & & & & 0 & & & $\circ$ & & & $\circ$ & & & $\begin{array}{l}8 \\
\dot{0} \\
\dot{w}\end{array}$ & & & $\dot{\circ}$ & & 8 & & & & \\
\hline
\end{tabular}


received. The industrial experts were from the Jahjarm bauxite mine of Iran. These questionnaires consisted of their impacting factors according to Figure 3. The experts were asked to evaluate the direct influence of factors located in the rows on the factors located in columns. In the following segment, the implementation of the fuzzy DEMATEL method for environmental impacting factors is described. By undertaking the aforementioned steps, matrix $\mathrm{T}$ is tabulated in Table 3.

By implementing the steps of the fuzzy DEMATEL method, the vectors of (r), and (c) are calculated for aspects, and the obtained results are presented in Table 4. Finally, the fuzzy and non-fuzzy weights were calculated using Equation (9) and the results are shown in Table 5 and Figure 5.

Table 4: Results of total relationships matrix for impacting factors

\begin{tabular}{|l|c|c|}
\hline Impacting factors & $\mathrm{r}$ & $\mathrm{c}$ \\
\hline $\mathrm{C}_{11}$ & $(0.26,0.36,0.62)$ & $(0.22,0.45,0.73)$ \\
\hline $\mathrm{C}_{12}$ & $(0.24,0.42,0.59)$ & $(0.26,0.46,0.72)$ \\
\hline $\mathrm{C}_{13}$ & $(0.21,0.37,0.67)$ & $(0.22,0.36,0.68)$ \\
\hline $\mathrm{C}_{14}$ & $(0.12,0.2,0.51)$ & $(0.21,0.31,0.65)$ \\
\hline $\mathrm{C}_{15}$ & $(0.15,0.33,0.56)$ & $(0.3,0.45,0.77)$ \\
\hline $\mathrm{C}_{16}$ & $(0.28,0.47,0.69)$ & $(0.15,0.31,0.64)$ \\
\hline $\mathrm{C}_{21}$ & $(0.29,0.41,0.59)$ & $(0.29,0.48,0.8)$ \\
\hline $\mathrm{C}_{31}$ & $(0.26,0.44,0.72)$ & $(0.26,0.32,0.59)$ \\
\hline $\mathrm{C}_{32}$ & $(0.26,0.5,0.71)$ & $(0.23,0.49,0.45)$ \\
\hline $\mathrm{C}_{33}$ & $(0.3,0.44,0.66)$ & $(0.15,0.28,0.47)$ \\
\hline $\mathrm{C}_{34}$ & $(0.26,0.41,0.72)$ & $(0.32,0.43,0.54)$ \\
\hline
\end{tabular}

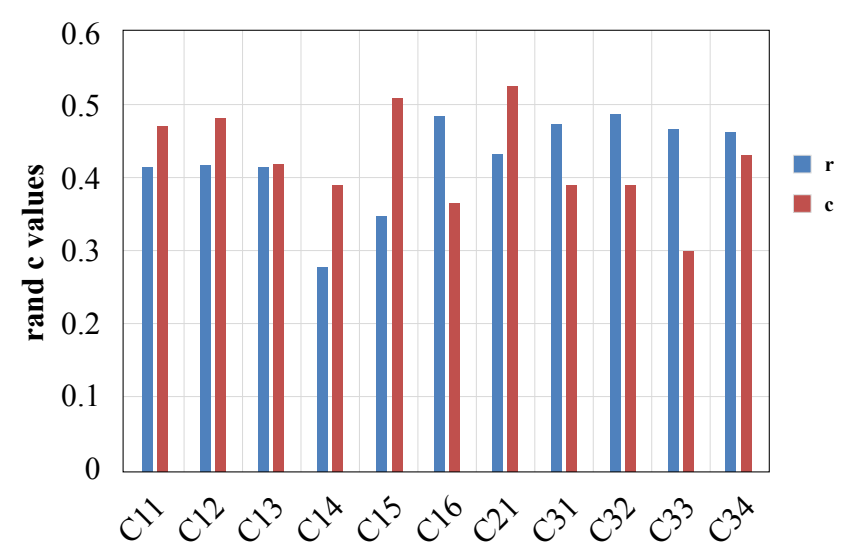

Figure 4: The $r$ and c vectors for impacting factors

In is noted from Table $\mathbf{4}$ and Figure $\mathbf{4}$ the fixed price is the most total received influence among the impacting factors. Whereas skill and knowledge have a total received influence with the smallest (c) value. When the fixed price increases or decreases, other economic impacting factors will change. For example, when salary increases, the fixed price, employment of local work-
Table 5: The results of weighting on impacting factors

\begin{tabular}{|l|c|c|}
\hline Impacting factor & Fuzzy weight & $\begin{array}{c}\text { Deterministic } \\
\text { weight (\%) }\end{array}$ \\
\hline $\mathrm{C}_{11}$ & $(0.09,0.09,0.1)$ & 9.37 \\
\hline $\mathrm{C}_{12}$ & $(0.1,0.1,0.09)$ & 9.67 \\
\hline $\mathrm{C}_{13}$ & $(0.11,0.08,0.8)$ & 9.10 \\
\hline $\mathrm{C}_{14}$ & $(0.06,0.06,0.08)$ & 6.80 \\
\hline $\mathrm{C}_{15}$ & $(0.09,0.09,0.09)$ & 9.04 \\
\hline $\mathrm{C}_{16}$ & $(0.08,0.09,0.1)$ & 8.89 \\
\hline $\mathrm{C}_{21}$ & $(0.09,0.09,0.1)$ & 9.43 \\
\hline $\mathrm{C}_{31}$ & $(0.1,0.1,0.1)$ & 9.93 \\
\hline $\mathrm{C}_{32}$ & $(0.11,0.11,0.8)$ & 9.66 \\
\hline $\mathrm{C}_{33}$ & $(0.09,0.08,0.08)$ & 8.26 \\
\hline $\mathrm{C}_{34}$ & $(0.11,0.1,0.09)$ & 9.85 \\
\hline
\end{tabular}

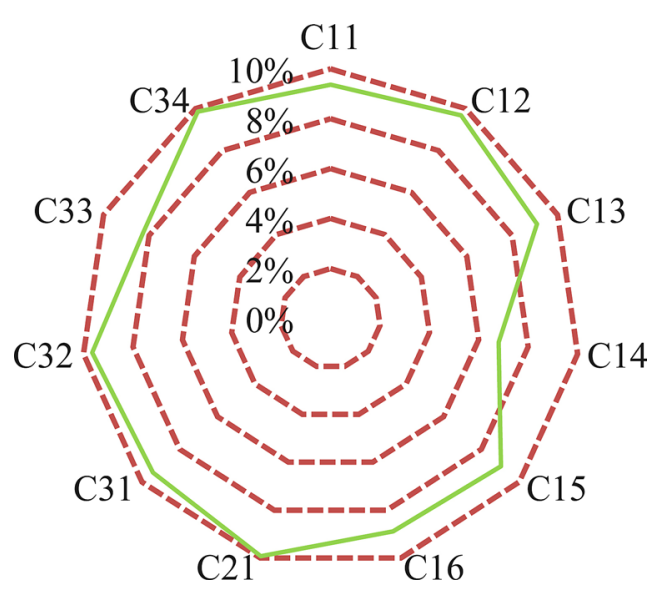

Figure 5: The impacting factors' weight

force, and local satisfaction will also increase, but early closure of the mine will decrease. For the same reason, the employment of a local workforce has the most total received influence, and the results also confirm this point. According to the calculations, early closure of the mine is the most total exerted influence. Whereas noise is the least total exerted influence factor since it does not increase or decrease any impacting factors.

As it can be concluded from Table 5 and Figure 5, fixed price has the most weight. Whereas the noise is the impacting factor which has the minimum importance in the assessment of the system.

In order to introduce FDSDI, based on literature, the mining report, analysis and our own knowledge, standard guidelines for sustainable development mining, guidelines for Environmental Impact Assessment (EIA) for mining projects, and guidelines for social responsibility in outbound mining investments (International Atomic Energy Agency (IAEA), 2006; Rwanda Environmental Management Authority (REMA), 2007; Department of Resources, Energy and Tourism, 2011; Vintro and Comajuncosa, 2010; Laurence et la., 2011; Sadler and Dalal-Clayton, 2012; Shen et al., 
Table 6: Rating table of sustainable development impacting factors

\begin{tabular}{|l|c|c|c|c|c|}
\hline \multirow{2}{*}{ impacting factor } & \multicolumn{5}{|c|}{ Class } \\
\cline { 2 - 6 } & 0 & 1 & 2 & 3 & 4 \\
\hline $\mathrm{C}_{11}\left(\mathrm{gr} . \mathrm{m}^{3}\right)$ & $1>$ & $1-5$ & $5-10$ & $10-20$ & $>20$ \\
\hline $\mathrm{C}_{12}(\mathrm{mg} .1)$ & $1>$ & $1-3$ & $3-5$ & $5-7$ & $>7$ \\
\hline $\mathrm{C}_{13}(\mathrm{mg} \cdot \mathrm{kg})$ & $10>$ & $10-50$ & $50-100$ & $100-150$ & $>150$ \\
\hline $\mathrm{C}_{14} \mathrm{~dB}(\mathrm{~A})$ & $60>$ & $60-75$ & $75-85$ & $85-95$ & $>150$ \\
\hline $\mathrm{C}_{15}$ & Very favourable & & Fair & & Very unfavourable \\
\hline $\mathrm{C}_{16}(\mathrm{kWh} .(\mathrm{t} \cdot \mathrm{km}))$ & $0.6>$ & $0.6-2.4$ & $2.4-4.2$ & $4.2-6$ & $>6$ \\
\hline $\mathrm{C}_{21}(\%)$ & $15>$ & $15-15.5$ & $15.5-16$ & $16-16.5$ & $>16.5$ \\
\hline $\mathrm{C}_{31}(\%)$ & $12>$ & $12-20$ & $20-28$ & $>28$ & \\
\hline $\mathrm{C}_{32}$ & Very favourable & & Fair & & Very unfavourable \\
\hline $\mathrm{C}_{33}$ & Very unfavourable & Unfavourable & Fair & Favourable & Very favourable \\
\hline $\mathrm{C}_{34}$ & Very favourable & Favourable & Fair & Unfavourable & Very unfavourable \\
\hline
\end{tabular}

2015; Anuru-yeng, 2019), all impacting factors were classified into five classes with respect to their role in SD. A corresponding rate of 0 to 4 was assigned to each class, and the score of each parameter is presented in Table 6 for environmental, economic and social impacting factors, respectively.

FDSDI represents the Fuzzy DEMATEL Sustainable Development Index. The rating of FDSDI for sustainability is calculated as Equation 10 (Hudson 1992):

$$
\sum_{i=1}^{11} a_{i} \frac{P_{i}}{P_{\text {Maxi }}}
$$

Where:

$\mathrm{a}_{\mathrm{i}}$ - the weight of $i^{\text {th }}$ parameter,

$\mathrm{P}_{\mathrm{i}}$ - the rate of $i^{\text {th }}$ parameter ( 0 to 4$)$,

$\mathrm{P}_{\text {max }}$ - the maximum rate of $i^{\text {th }}$ parameter.

Using FDSDI computational procedure, the minimum and maximum possible ratings are 0 and 100, respectively. Sustainability was classified into three groups, depending on the value of FDSDI from low to high as listed in Table 7.
Table 7: sustainability classification based on FDSDI

\begin{tabular}{|l|c|c|}
\hline FDSDI class & FDSDI & sustainability description \\
\hline I & $0-33$ & Low \\
\hline II & $33-66$ & Moderate \\
\hline III & $66-100$ & High \\
\hline
\end{tabular}

\subsection{Case study: Jahjarm bauxite mine}

The Jahjarm bauxite mine is located in the North Khorasan province, $19 \mathrm{~km}$ northeast of Jahjarm city. This mine has 18 zones named Golbini ${ }_{1}, \ldots$, Golbini ${ }_{8}$ $\left(G_{1}, G_{2}, \ldots, G_{8}\right), Z_{1}, \ldots, Z_{1} o u_{4}\left(Z_{1}, . ., Z_{4}\right)$, TaGoei1,.., TaGoei $_{6}\left(\mathrm{TG}_{1}, \mathrm{TG}_{2}, \ldots, \mathrm{TG}_{6}\right)$ and has more than 20 million tons of bauxite and it is Iran's largest bauxite mine. For every 3 tons of extraction, there are 2 tons of waste and 1 ton of ore. By and large, the bauxite zone of this mine has four types, as following:

(1) Upper kaolin bauxite;

(2) Hard bauxite;

(3) Soft shale bauxite; and

(4) Kaolin bauxite.

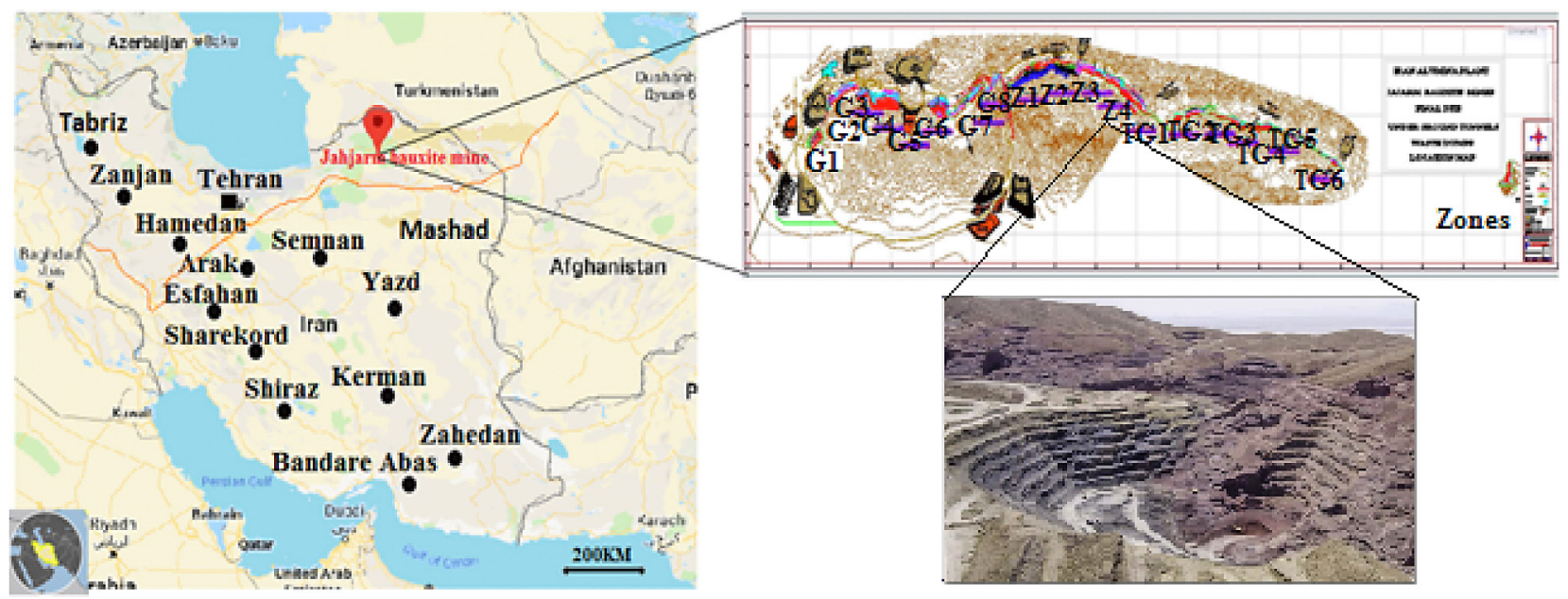

Figure 6: Location Jahjarm bauxite mines in Iran 
Table 8: Calculation of FDSDI for zones of the Jahjarm bauxite mine

\begin{tabular}{|l|c|c|c|c|c|c|c|c|c|c|c|c|c|}
\hline Item & \multicolumn{10}{|c|}{ Value of parameters } & \multicolumn{10}{l|}{} \\
\hline $\mathrm{a}_{\mathrm{i}}$ & 9.37 & 9.67 & 9.10 & 6.80 & 9.04 & 8.89 & 9.43 & 9.93 & 9.66 & 8.26 & 9.85 & & \\
\hline $\mathrm{P}_{\text {imax }}$ & 4 & 4 & 4 & 4 & 4 & 4 & 4 & 4 & 4 & 4 & 4 & & \\
\hline $\mathrm{P}_{\mathrm{i}}$ & $\mathrm{C}_{11}$ & $\mathrm{C}_{12}$ & $\mathrm{C}_{13}$ & $\mathrm{C}_{14}$ & $\mathrm{C}_{15}$ & $\mathrm{C}_{16}$ & $\mathrm{C}_{21}$ & $\mathrm{C}_{31}$ & $\mathrm{C}_{32}$ & $\mathrm{C}_{33}$ & $\mathrm{C}_{34}$ & FDSDI & FDSDI class \\
\hline $\mathrm{G}_{1}$ & 3 & 2 & 4 & 3 & 2 & 4 & 3 & 2 & 2 & 1 & 2 & 63.82 & Moderate \\
\hline $\mathrm{G}_{2}$ & 3 & 3 & 3 & 3 & 4 & 4 & 3 & 3 & 4 & 3 & 2 & 79.76 & High \\
\hline $\mathrm{G}_{3}$ & 3 & 2 & 3 & 3 & 2 & 4 & 3 & 3 & 2 & 3 & 3 & 70.29 & High \\
\hline $\mathrm{G}_{4}$ & 3 & 3 & 3 & 2 & 2 & 3 & 3 & 2 & 2 & 2 & 3 & 64.32 & Moderate \\
\hline $\mathrm{G}_{5}$ & 3 & 3 & 3 & 3 & 2 & 4 & 2 & 2 & 2 & 2 & 3 & 66.06 & High \\
\hline $\mathrm{G}_{6}$ & 2 & 2 & 2 & 2 & 2 & 4 & 2 & 2 & 2 & 2 & 3 & 57.12 & Moderate \\
\hline $\mathrm{G}_{7}$ & 3 & 3 & 3 & 3 & 4 & 3 & 3 & 3 & 2 & 3 & 4 & 77.59 & High \\
\hline $\mathrm{G}_{8}$ & 3 & 4 & 3 & 3 & 4 & 4 & 3 & 3 & 4 & 3 & 4 & 87.10 & High \\
\hline $\mathrm{Z}_{1}$ & 3 & 3 & 3 & 2 & 2 & 3 & 2 & 2 & 2 & 2 & 3 & 62.10 & Moderate \\
\hline $\mathrm{Z}_{2}$ & 3 & 2 & 3 & 3 & 4 & 3 & 3 & 2 & 2 & 2 & 2 & 65.83 & Moderate \\
\hline $\mathrm{Z}_{3}$ & 3 & 3 & 3 & 3 & 4 & 3 & 3 & 3 & 2 & 3 & 3 & 75.13 & High \\
\hline $\mathrm{Z}_{4}$ & 4 & 4 & 2 & 2 & 4 & 4 & 4 & 4 & 2 & 3 & 4 & 85.01 & High \\
\hline $\mathrm{TG}_{1}$ & 3 & 3 & 3 & 3 & 4 & 3 & 1 & 1 & 2 & 1 & 4 & 64.30 & Moderate \\
\hline $\mathrm{TG}_{2}$ & 3 & 3 & 3 & 3 & 4 & 3 & 3 & 3 & 4 & 3 & 3 & 79.96 & High \\
\hline $\mathrm{TG}_{3}$ & 3 & 3 & 3 & 3 & 2 & 3 & 1 & 1 & 2 & 2 & 4 & 61.68 & Moderate \\
\hline $\mathrm{TG}_{4}$ & 3 & 3 & 3 & 3 & 2 & 4 & 3 & 3 & 2 & 3 & 3 & 72.71 & High \\
\hline $\mathrm{TG}_{5}$ & 3 & 3 & 3 & 3 & 4 & 3 & 3 & 3 & 0 & 3 & 3 & 70.30 & High \\
\hline $\mathrm{TG}_{6}$ & 3 & 2 & 3 & 2 & 4 & 4 & 1 & 1 & 0 & 3 & 2 & 56.82 & Moderate \\
\hline
\end{tabular}

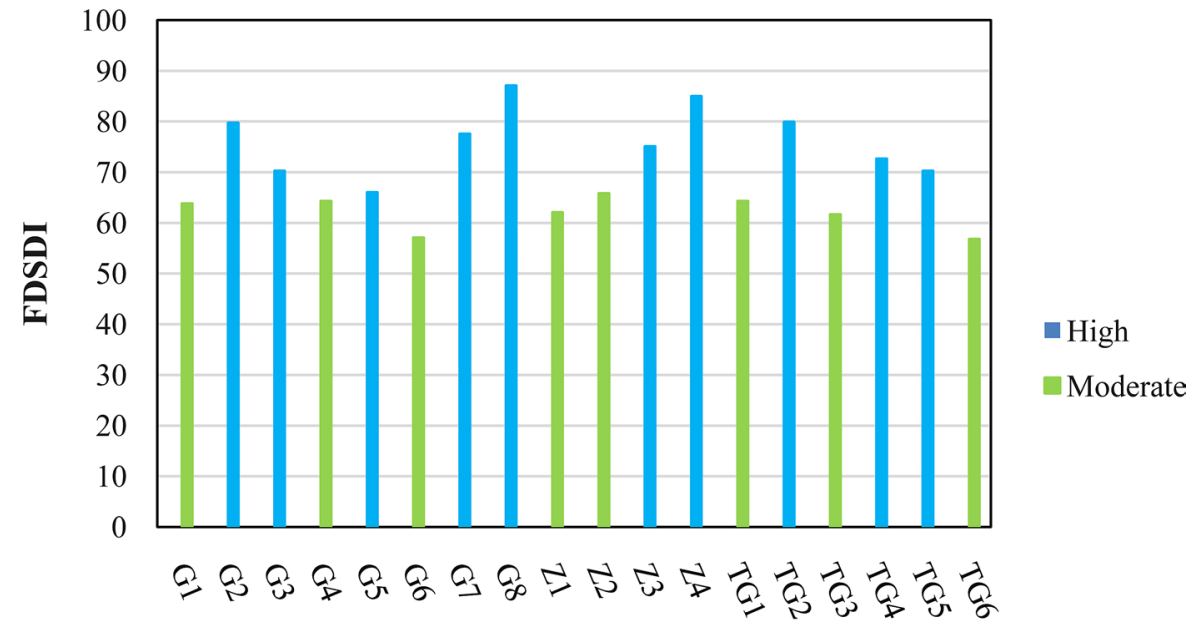

zone

Figure 7: Calculation of FDSDI for the zones of the Jahjarm bauxite mine

The population of Jahjarm city is about 40,000. The climate of the Jahjarm Desert is cold and dry in the winter and hot in the summer. The minimum temperature is $-6.5^{\circ} \mathrm{C}$ and the maximum is $36.5^{\circ} \mathrm{C}$. The annual rainfall of the area is $179.7 \mathrm{~mm}$ and the relative humidity of the area is $84 \%$ and at least $4 \%$. The wind direction of the area is mainly from the west, northwest and northeast. This area has unique vegetation, also known for its wild- life refuge where the Iranian cheetah lives. The mining area is a mountain range along the east-west part of the north of the Jahjarm Desert which is about 1000 meters above sea level. Generally, the stratigraphy and physical characteristics of the existing structures in the region as well as the structural stresses have played a key role in determining the geological status of the area. The location of the Jahjarm bauxite mine is shown in Figure 6. 


\section{Results and discussion}

In the present article, a general approach was developed for an impact assessment of mining activities on SD by using the fuzzy DEMATEL method. For this purpose, 11 impacting factors were chosen that affect sustainability development; in the following the fuzzy DEMATEL was used to weight them and to create a classification system. Then, FDSDI determined the total score of the mine based on the offered class system. FDSDI values are between 0 and 100 and present the sustainability level in three classes from low to high level. This new index has been implemented in rating $\mathrm{SD}$ in the bauxite Jahjarm mine. Based on this index, as it can be seen in Table 8 and Figure 7, $\mathrm{G}_{2}, \mathrm{G}_{3}, \mathrm{G}_{5}, \mathrm{G}_{7}$, $\mathrm{G}_{8}, \mathrm{Z}_{3}, \mathrm{Z}_{4}, \mathrm{TG}_{2}, \mathrm{TG}_{4}$, and $\mathrm{TG}_{5}$ are at the highest level of sustainability, with values of $79.76,70.29,66.06,77.59$, $87.10,75.13,85.01,79.96,72.71,70.30$ respectively; and G1, G4, G6, Z1, Z2, TG1, TG3, and TG6 are at the moderate level of sustainability, with values of 63.82 , $64.32,57.12,62.10,65.83,64.30,61.68$ and 56.82 respectively.

It is noteworthy that at present, this classification and indexing for determining the scope of the index in each class, also included evidence and events that occurred in each class in the past. In general, FDSDI is a useful scientific and systematic method for analyzing many parameters. Field experiences and observations show that the actual state of this mine is in accordance with the FDSDI approach. Therefore, in light of the results of this study, it can be concluded that FDSDI has high validity for the evaluation of SD in the Jahjarm bauxite mine. However, given the definitive definition of the intervals and the amount assigned to each interval ( 0 to 4$)$ in Table 6, it is suggested that fuzzy logic be used to match the reality and reduce the uncertainty of the judgments in the results because this method allows you to determine the rate of each class and its intervals.

\section{Conclusion}

In the present study, a sustainable development index involving the fuzzy DEMATEL method was developed to evaluate the impacts of mining activities. The advantage of this approach compared with other studies include developing a sustainable development index assessment method based on the specific impacting factors for each mining project and considering the relative weight of each impacting factor in the assessment process. Also, to assess the sustainability of bauxite mining, its positive and negative impacts can be evaluated simultaneously. This general approach can be accomplished for each bauxite mining project, along with using specific impacting factors, based on the special conditions related to the mining method, and region conditions. This approach is suitable in assessing the status of SD in a bauxite mining region and specifying the priorities for improving the SD situation by determining the vulnerable and critical SD criteria. The proposed approach was implemented in the Jahjarm bauxite mine of Iran. The results indicated that its sustainability varies between 56.82 and 87.10. Accordingly, the best and worst zones are Golbini $_{8}$ and $\mathrm{TaGoei}_{6}$, respectively. However, to achieve the main objective of SD, corrective measures with the priority of vulnerable criteria should be taken into account to improve this zone.

\section{Acknowledgment}

This work was supported by Shahrood University of Technology [project number 11040].

\section{References}

Adibi, N. and Ataee-pour, M. (2015): Consideration of sustainable development principles in ultimate pit limit design. Environmental earth sciences, 74, 4699-4718.

Adibi, N., Ataee-pour, M. and Rahmanpour, M. (2015): Integration of sustainable development concepts in open pit mine design. Journal of Cleaner Production, 108, 10371049.

Allan, R. (1995): Introduction: sustainable mining in the future. Journal of Geochemical Exploration, 52, 1-4.

Allen, H.E.K. (1991): Mining and sustainable development: the role of the professional. Minerals Industry International, 1001, 5-8.

Amirshenava, S. and Osanloo, M. (2018): Mine closure risk management: an integration of 3D risk model and MCDM techniques. Journal of cleaner production, 184, 389-401.

Anuru-yeng, D. A. (2019): The environmental and health implications of artisanal small gold mining in kadema, Upper East Region, Ghana. (Doctoral dissertation).

Auty, R. and Warhurst, A. (1993): Sustainable development in mineral exporting economies. Resources Policy, 19, 1, 14-29.

Badiozamani, M. M. and Askari-Nasab, H. (2014): Integration of reclamation and tailings management in oil sands surface mine planning. Environmental modelling and software, 51, 45-58.

Buchanan, S. and Marques, J. C. (2018): How home country industry associations influence MNE international CSR practices: Evidence from the Canadian mining industry. Journal of World Business, 53, 1, 63-74.

Brundtland, G. H. (1987): Report of the World Commission on environment and development:" our common future". United Nations.

Carbon, B. (1997): Sustainable development and the evolving agenda for environmental protection in the mining industry. Industry and Environment, 20, 4, 10-13.

Campbell, J. T., Eden, L. and Miller, S. R. (2012): Multinationals and corporate social responsibility in host countries: Does distance matter?. Journal of International Business Studies, 43, 1, 84-106.

Dashwood, H. S. (2012): The rise of global corporate social responsibility: Mining and the spread of global norms. Cambridge University Press, 303p. 
Department of Resources, Energy and Tourism. (2011): A guide to leading practice sustainable development in mining. Australian, 210p.

DES, U. (2013): World economic and social survey (2013): sustainable development challenges. United Nations, Department of Economic and Social Affairs, New York, 123-136.

Dubiński, J. (2013): Sustainable development of mining mineral resources. Journal of Sustainable Mining, 12, 1, 1-6.

Eggert, R. (2006): Mining, sustainability and sustainable development. In: Maxwell, P.M. (Ed.). Australian Mineral Economics.

Egri, C.P. and Ralston, D.A. (2008): Corporate responsibility: a review of international management research from 1998 to 2007. Journal of International Management, 14, 4, 319-339.

Fontela, E. and Gabus, A. (1972): World Problems an Invitation to Further Thought within the Framework of DEMATEL. Battelle Geneva Research Centre. Switzerland. Geneva.

Fontela, E. and Gabus A. (1974): DEMATEL, innovative methods. Report No. 2. Structural analysis of the world problematique. Battelle Geneva Research Institute.

Fontela, E. and Gabus A. (1976): The DEMATEL observer. Battelle Institute. Geneva Research Center.

Gardner, J. H. and Bell, D. T. (2007): Bauxite mining restoration by Alcoa World Alumina Australia in Western Australia: social, political, historical, and environmental contexts. Restoration Ecology, 15, 3-10.

Gladwin, T. N., Kennelly, J. J. and Krause, T. S. (1995): Shifting paradigms for sustainable development: Implications for management theory and research. Academy of management Review, 20, 4, 874-907.

Hilson, G. and Basu, A. J. (2003): Devising indicators of sustainable development for the mining and minerals industry: An analysis of critical background issues. The International Journal of Sustainable Development and World Ecology, 10, 4, 319-331.

Hilson, G. and Murck, B. (2000): Sustainable development in the mining industry: clarifying the corporate perspective. Resources policy, 26, 4, 227-238.

Horowitz, L. (2006): Mining and sustainable development. Journal of cleaner production, 14, 3-4, 307-308.

Hudson, J. (1992): Rock engineering systems. Theory and practice.

International Atomic Energy Agency (IAEA), (2006): Guidebook on environmental impact assessment for in situ leach mining projects, Austria, $170 \mathrm{p}$.

James, P. M. (1999): The miner and sustainable development. Mining Engineering, 51, 6, 89-92.

Lad, R. J. and Samant, J. S. (2015): Impact of bauxite mining on soil: a case study of bauxite mines at Udgiri, Dist-Kolhapur, Maharashtra State, India. International Research Journal of Environment Sciences, 4, 2, 77-83.

Laurence, D., Stamford, C., Barry, S., Oosting, N., Andryszczk, H., Fawsett, M. and Jones, D. (2011): A guide to leading practice sustainable development in mining. Australian Government Department of Resources and Tourism, Canberra.
Leblanc, M., Tweed, S., Lyon, B. J., Bailey, J., Franklin, C. E., Harrington, G. and Suckow, A. (2015): On the hydrology of the bauxite oases, Cape York Peninsula, Australia. Journal of Hydrology, 528, 668-682.

Learmont, D. (1997): Mining must show that it is sustainable. Mining Engineering, 49, 1, 1-12.

Marker, B., Petterson, M. G., and McEvoy, F. (Eds.). (2005): Sustainable minerals operations in the developing world. Geological Society of London.

Mikesell, R. F. (1994): Sustainable development and mineral resources. Resources Policy, 20, 2, 83-86.

Mohammadi, S., Ataei, M. and Kakaie, R. (2018): Assessment of the importance of parameters affecting roof strata cavability in mechanized longwall mining. Geotechnical and Geological Engineering, 36, 4, 2667-2682.

Moradi, G. and Osanloo, M. (2015): Prioritizing sustainable development criteria affecting open pit mine design: a mathematical model. Procedia Earth and Planetary Science, 15, 813-820.

Monjezi, M., Shahriar, K., Dehghani, H. and Namin, F. S. (2009): Environmental impact assessment of open pit mining in Iran. Environmental geology, 58, 1, 205-216.

Narrei, S. and Osanloo, M. (2015): Optimum cut-off grade's calculation in open pit mines with regard to reducing the undesirable environmental impacts. International Journal of Mining, Reclamation and Environment, 29, 3, 226-242.

Norouzi Masir, R., Khalokakaie, R., Ataei, M. and Mohammadi, S. (2018): Structural analysis of impacting factors of sustainable development in underground coal mining using DEMATEL method. Journal of Mining and Environment, 9, 3, 567-579.

Osanloo, M. and Rahmanpour, M. (2017): Sustainable open pit mine design, ultimate pit limit and cut-off grade determination. Lap Lambert Academic Publishing.

Owen, J.R. and Kemp, D. (2017): Extractive Relations: Countervailing Power and the Global Mining Industry. Sheffield, UK.

Pavloudakis, F., Galetakis, M. and Roumpos, C. (2009): A spatial decision support system for the optimal environmental reclamation of open-pit coal mines in Greece. International Journal of Mining, Reclamation and Environment, 23, 4, 291-303.

Phillips, J. (2012): Using a mathematical model to assess the sustainability of proposed bauxite mining in Andhra Pradesh, India from a quantitative-based environmental impact assessment. Environmental Earth Sciences, 67, 6, 1587-1603.

Rahimi, E., and Ghasemzadeh, H. (2015): A new algorithm to determine optimum cut-off grades considering technical, economical, environmental and social aspects. Resources Policy, 46, 51-63.

Rahmanpour, M. and Osanloo, M. (2017): A decision support system for determination of a sustainable pit limit. Journal of cleaner production, 141, 1249-1258.

Rajaram, V., Dutta, S. and Parameswaran, K. (2005): Sustainable Mining Practices: a Global Perspective. Taylor and Francis Group, London, 324 p.

Rashidinejad, F., Osanloo, M. and Rezai, B. (2008): An environmental oriented model for optimum cut-off grades in 
open pit mining projects to minimize acid mine drainage. International Journal of Environmental Science and Technology, 5, 2, 183-194.

Ramirez-Rodriguezm, G.D. and Rozgonyi, T.G. (2004): Evaluating the impact of environmental considerations in open pit mine design and planning. Proceedings of the eighth international symposium on environmental issues and waste management in energy and mineral production, 125-131.

Rwanda Environmental Management Authority (REMA). (2009): Guidelines for Environmental Impact Assessment for Wetland Management, Rwanda, $57 \mathrm{p}$.

Sachs, J. D. and Reid, W. V. (2006): Investments toward sustainable development. Science, 312, 5776, 1002-1002.

Sadler, B. and Dalal-Clayton, D. B. (2012): Strategic environmental assessment: a sourcebook and reference guide to international experience. Earthscan, 382p.

Shen, L., Muduli, K. and Barve, A. (2015): Developing a sustainable development framework in the context of mining industries: AHP approach. Resources Policy, 46, 15-26.

Srikanth, R. and Nathan, H. S. K. (2018): Towards sustainable development: planning surface coal mine closures in India. Contemporary Social Science, 13, 1, 30-43.
Stoughton, A. M. and Ludema, J. (2012): The driving forces of sustainability. Journal of Organizational Change Management, 25, 4, 501-517.

Tilton, J. E. (1996): Exhaustible resources and sustainable development: Two different paradigms. Resources Policy, 22, 1-2, 91-97.

Temper, L. and Martinez-Alier, J. (2013): The god of the mountain and Godavarman: Net Present Value, indigenous territorial rights and sacredness in a bauxite mining conflict in India. Ecological Economics, 96, 79-87.

Vintro, C. and Comajuncosa, J. (2010): Corporate social responsibility in the mining industry: criteria and indicators. Dyna, 77, 161, 31-41.

Vivoda, V. and Kemp, D. (2019): How do national mining industry associations compare on sustainable development? The Extractive Industries and Society, 6, 1, 22-28.

Von Below, M. A. (1993): Sustainable mining development hampered by low mineral prices. Resources Policy, 19, 3, 177-181.

\section{SAŽETAK}

\section{Predstavljanje novoga indeksa održivoga razvoja u rudarstvu boksita metodom fuzzy DEMATEL}

Rudarstvo kao ekonomska aktivnost može imati pozitivne i negativne učinke na zajednicu. Ti negativni učinci zajedno s nekim društvenim, ekonomskim i ekološkim utjecajima rudarske djelatnosti prijete ostvarenju ciljeva održivoga razvoja (SD). Stoga je procjena utjecaja na indekse održivoga razvoja važna za zaštitu rudarske djelatnosti u skladu s ciljevima održivoga razvoja. Stoga je predložena sustavna klasifikacija pomoću tehnike neodređenoga ispitivanja i laboratorija za ocjenjivanje (fuzzy dematel) tehnike za proučavanje i analizu jedanaest međusobnih odnosa faktora koji djeluju na otvorenim kopovima. Kako se ova tehnika temelji na mišljenju stručnjaka, primijenjeno je neizrazito kodiranje. Na taj je način izabrana težina utjecajnih čimbenika i povezana ocjena kako bi se razvio nov sustav klasifikacije. Na temelju predloženoga sustava ocjenjivanja uveden je novi indeks održivoga razvoja u rudarstvu boksita metodom fuzzy DEMATEL (FDSDI) za opis kvalitativne i kvantitativne razine na razini sustava. Primjena FDSDI-ja ispitivana je u rudniku boksita kao studija slučaja. Rezultati pokazuju da je FDSDI jednostavan i učinkovit alat za procjenu održivosti u iskopavanju boksita. Općenito, provedena tehnika predstavlja sustavan pristup za holističku analizu faktora utjecaja održivoga razvoja u rudnicima.

\section{Ključne riječi:}

ispitni i ocjenjivački laboratorij za odlučivanje, klasifikacijski sustav, zona, rudnik boksita Jahjarm

\section{Authors contribution}

Mohammad Ataei (Full Professor): initialized the idea, completed a literature review and participated in all work stages such as providing questionnaires designed to collect the necessary data, and distributed them among the experts. Raziye Norouzi Masir (Ph.D. Candidate): she did analysis of the data collected from the questionnaires. Also managed the whole process and supervised it from the beginning to the end. 